\title{
An Explanation of Movements in the Labor Force Participation Rate, 1957-76
}

\author{
LEONALL C. ANDERSEN
}

$S$ the economy has moved through recession and into the recent period of recovery, the unemployment rate, an important consideration in economic stabilization policy, has displayed a different pattern from that which had been observed in such cycles before 1973. In particular, the average level of the unemployment rate has remained uncharacteristically high for such an extended period of expansion. One reason often cited for this development is an unusual increase in the labor force participation rate since 1973. This ratio, which measures the proportion of the population of labor force age who either have a job or are looking for one, has risen markedly.

The participation rate decreased from $\mathrm{I} / 1957$ to IV/1964 and subsequently rose through the period ending IV/1976. Since considerable time is required to identify a change in trend, analysis of labor market conditions, for some time after 1964, did not take into consideration the reversal in the trend of the participation rate.

This study develops a theoretical model of the behavior which determines labor force participation. Parameters of the model are estimated and used to explain the observed movements in the labor force participation rate from 1957 to 1976.

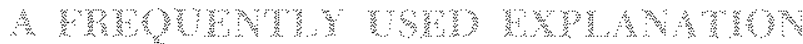

A prominent and widely accepted explanation of the labor market behavior of individuals is based on an analysis of the relative strengths of the "discour- aged worker" and the "additional-worker" effects. ${ }^{1}$ The discouraged worker effect involves a negative relationship between the labor force participation rate and the unemployment rate, while the additional worker effect involves a positive relationship.

Empirical evidence has been presented which indicates that the discouraged worker effect is dominant and, therefore, on balance, there is a negative relationship between the labor force participation rate and the unemployment rate. William $G$. Bowen and $T$. Aldrich Finegan, in an extensive study of the factors influencing the labor force participation rate, concluded that their cross-sectional findings ". . . raise serious doubts whether the additional-worker effect dominated the participation response of any demographic group, regardless of how narrowly it might be defined." Several studies using time series

\footnotetext{
The discouraged worker effect is based on the postulate that decisions to enter or leave the labor market are influenced to a major extent by the "availability" of jobs. An increase in job availability, as indicated by a general decline in the unemployment rate, induces individuals to enter the labor market; a decrease in job avallabilty causes unemployed workers to become discouraged and to leave the labor market. The additional worker effect is based on the postulate that a rise in general unemployment induces additional workers from each household to enter the labor market in an attempt to maintain household income.

2Willam G. Bowen and T. Aldich Finegan, The Economics of Labor Force Partichation (Princeton: Princeton University Press, 1969), p. 487, Using time series data, however, the athors reported that, ". . . we have found no convincing evidence in the postwat record that short-period changes in the overall rate of unemployment have had a large impact on the labor force participation rate of any population group on the than teenagers and possibly males $65 *$ " [p. 515]. But,
other than
} 
data have also found evidence supporting such a conclusion. ${ }^{3}$

Labor market behavior of individuals since 1973 , however, has not been consistent with the implications of the above mentioned research findings. During the last recession, the labor force participation rate remained scarcely unchanged, despite a marked rise in the unemployment rate which began in late 1974 . The discouraged worker hypothesis would have predicted a fall. Then, when the unemployment rate fell only moderately following the trough of the recession, the participation rate rose sharply; whereas, the results of these studies would imply a significantly smaller increase. Also, the participation rate is currently at a higher level, for the prevailing level of the unemployment rate, than would be indicated by historical relationships. Recent experience thus casts serious doubts on the validity of the discouraged worker explanation of movements in the labor force participation rate.

\section{An A}

Since the late 1960s, several studies of labor market behavior have taken into consideration the influence of such economic factors as changes in the real wage rate and nonlabor real income on the decisions of individuals to offer hours of work in the labor market. ${ }^{4}$ The model developed in this study proceeds along similar lines.

This article consists of two parts. The first part develops a model of the overall labor force participation rate and is directed to those readers who are in

they prefaced, "In the light of the intrinsic limitations of time series regressions . . . it is difficult to place much confidence in the precise numerical results of these regressions."

"Thamas Dernburg and Kemeth Strand, "Cyclical Variation in Civilian Labor Force Participation," Review of Economics and Statistics (November 1964), pp. 378-91; Peter S. Barth, "Unemployment and Labor Force Participation," Southern Economic Journal (January 1968), pp. 375-82; Alfred Tella,

"The Relation of Labor Force to Employment" Industrial and Labor Relations Review (April 1964), pp, 454-69; George L. Perry, "Potential Output and Productivity," Brookings Papers on Economic Activity (1:1977), pp. 11-47.

4 Bowen and Finegan in their cross-sectional study did include many economic factors, along with the unemployment rate and various demographic considerations. They, however, treated the discouraged worker effect as being independent of strictly economic influences. Also see the seven studies reported in Glen G. Cain and Harold W. Watks, eds., Income Maintenance and Labor Supply: Econometric Studies (New York: Academic Press, 1973); Michael L. Wachter, "A Labor Supply Model for Secondary Workers," Review of Economies and Statistics (May 1972), pp. 141-51, and Robert E. Lucas, Jr. and Leonard A. Rapping, "Real Wage Rates, Employment, and Inflation," Journal of Political Economy (September/ October 1969), pp. 721-54. terested in the underlying economic theory and econometric procedures. The general reader may proceed directly to the second part which uses the model to analyze the factors influencing the participation rate from 1957 to 1976 .

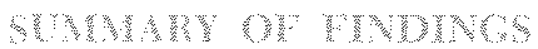

The model relates the current period overall labor force participation rate to: current period nonlabor real income per household (income received from assets and Social Security benefits); the average real wage rate; the average effective personal income tax rate; the average effective personal Social Security tax rate; the ratio of total population to population of labor force age ( 16 years and over); and the previous period's participation rate. The effect of each of the first five variables is decomposed into two components. The first one, a permanent component, is the level expected to prevail in the long run. The second one, a transitory component, is the difference (in the current period) between the actual and permanent level. The lagged participation rate reflects the length of time over which perceptions regarding the permanent levels of the first four variables are formed.

Statistical estimates of the response of the current period aggregate labor force participation rate for the sample period 1957 to 1976 indicate that this rate is negatively related to the transitory components of nonlabor real income per household, the average real wage rate, and the average effective personal income tax rate. The estimates also indicate negative responses to the permanent components of nonlabor real income per household and the ratio of total population to population labor force age, and a positive response to the permanent component of the average effective personal Social Security tax rate. The response of the participation rate to the permanent component of the average real wage rate changed from negative to positive after 1964. The responses with regard to the transitory components of the average effective personal Social Security tax rate and the ratio of total population to population of labor force age and to the permanent component of the average effective personal income tax rate were found to be zero.

There are two types of movements in the aggregate labor force participation rate to be explained. One type is the long-run trend which is related to changes in the permanent component of each variable. The 
other type is the short-run variations around the trend which are related to the transitory components and to the lag in the formation of the perceived levels of the permarient components.

Three subperiods were used to analyze movements in the aggregate labor force participation rate over the 1957-76 period. The first subperiod is 1957 to 1964, a period in which the trend of the participation rate was negative. The second one is 1965 to 1973 , when the trend changed to positive. The third one is 1974 to 1976 , the period cited in the introduction as providing evidence casting doubt on the validity of the commonly used discouraged worker explanation of movements in the labor force participation rate.

An analysis of the relative contribution of each factor to movements in the aggregate labor force participation rate indicates that trend influences tended to dominate in the first two subperiods. The major trend influence in the 1957-64 subperiod was the rise in the permanent average real wage rate. In the 1965-73 subperiod the major trend influence was the rise in the permanent average effective personal Social Security tax rate. In the last subperiod (197476), movements in the aggregate participation rate were dominated by transitory movements in the average real wage rate, nonlabor real income per household, and the average effective personal income tax rate.

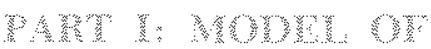

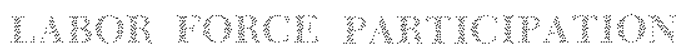

The model of aggregate labor force participation developed here uses time series data but incorporates many of the features found in previous studies which used cross-sectional data. The time series approach was selected to allow for an analysis of disequilibrium conditions. Such an analysis is not possible using the usual cross-sectional approach, because that approach applies only to data at a given point in time. An important feature of the cross-sectional studies, which this model incorporates, is the labor force participation behavior of individuals as menbers of households. Within the household context, the decisions of individual members of a household to participate or not are highly interrelated. Previous time series studies of labor force participation have generally tended to omit such interrelationships. ${ }^{5}$

\footnotetext{
sFor examples of cross-sectional studies which incorporate interrelationships among household nembers regarding their labor force participation (or number of hours offered for work), see Bowen and Finegan, The Economics of Labor Force Participation, and Orley Ashenfelter and James Heck-
}

\section{Dowhingers}

An individual of labor force age is one who is 16 years old or over. The term household is defined as a single individual or a group of individuals who share (1) the total real income (after taxes) received by the group, (2) the amount of the total time of all members of labor force age allocated to such strictly intragroup activities as housekeeping, and (3) the grotp's jointly formed perceptions regarding the permanent levels of such factors as the household's total real income. Total real income consists of real wages received by employed members of the household, and nonlabor real income, which consists of real earnings from assets and Social Security payments. Available time is an individual's total number of hours in the current period less a pro rata share of the total number of hours of all members of the household of labor force age which are allocated to such activities as the direct production of goods and services for household consumption. It is presumed that there are both permanent and transitory components of all factors in. fluencing labor market participation in the current period." The permanent component is the level of a factor anticipated to prevail in the long run. The transitory component is the difference between the actual experience in the current period and the permanent component.

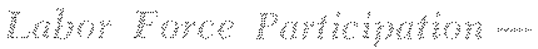

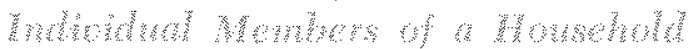

The model used in this study of the factors influencing the aggregate labor force participation rate is based on a theory of individual choice, defined in terms of goods and leisure. Or, viewed another way, the theory involves the allocation of an individual's time between hours of work offered in the labor market and hours of leisure. ${ }^{7}$

man. "The Estimation of Income and Substitution Effects in a Model of Family Labor Supply," Econometrica (January 1974), pp. 73-85. For examples of time series studies which do not take into consideration interelationships anong menbers of households see Lucas and Rapping, "Real Wage Rates, Employment, and Inflation;" Wachter, "A Labor Supply Model of Secondary Workers;" and Ray C. Fair, "Labor Force Participation, Wage Rates, and Money Illusion," Review of Economics and Statistics (May 1971), pp. 164-68.

BFor an exposition of these concepts, see Milton Friedman, $A$ Theory of the Consumption Function (Princeton: Princeton University Press, 1957), pp. 20-37. These concepts were used in Wachter, "A Labor Supply Model for Secondary Workers," and Lucas and Rapping, "Real Wage Rates, Employment, and Inflation."

"Contemporary analysis of the behavior of individuals in the labor market has been influenced greatly by Gary $\$$. Becker, "A Theory of the Allocation of Time, Economic Jounal 
It is postulated that the decision to be in the labor market in the current period depends on an individual's reservation wage rate relative to his decision wage rate. ${ }^{8}$ The reservation wage rate reflects an individual's preferences for goods and services relative to leisure. The decision wage rate reflects the opportunity available in the market to the individual for obtaining goods and services by allocating a unit of available time from leisure to labor market work.

On a more technical level, the reservation wage rate is an individual's marginal rate of substitution of goods and services for leisure when all available time is allocated to leisure. "The decision wage rate is the perceived amount of goods and services the individual can purchase if a unit of time is shifted from leisure to work. If the reservation wage rate is greater than or equal to the decision wage rate, the individual allocates all available time to leisure. If the reservation wage rate is less than the decision wage rate, the individual allocates part of avatlable time to participation in the labor market, either holding a job or seeking one.

Rerention Waye ma - An individual's reservation wage rate in the current period is postulated to be related to the perceived permanent levels of the household's wage and nonlabor sources of total real income, tax rates on income, and the number of individuals in the household. ${ }^{10}$ The greater the permanent nonlabor or real labor income of the household in the current period, other factors constant, the greater is each individual's reservation wage rate. ${ }^{11}$ The higher

(September 1965), pp. 493-517. Also see Jack Hirshleifer, Price Theory and Application (Englewood Cliffs, N.I.: Prentice Hall, 1976), pp. 380-85.

8See James Heckman, "Shadow Prices, Market Wages, and Labor Supply" Econometrica (July 1974), pp. 680-81, for a discussion of the argaments underlying this postulate.

It is the slopes of the indifference curves representing the preferences of an individual between market goods and services (as distinct from household produced goods and services) and leisure time at the point where the indifference curves intersect the available time constraint. In constructing the indifference curves, makket goods and services are on the vertical axis and hours of leisure are on the horizontal axis.

19The actual number of members in a household in the current period can be influenced by such umexpected events as deaths; the leaving of a menber to form a new household as a result of marriage, divorce or a desire to be indepen dent; the military draft or a reduction in armed forces; and the admission of new members, for example, an elderly parent. Given these ancertainties, the members of the household are assumed to have a jointly formed perception regard ing its permanent size in the current period. This study does not investigate the factors influeneing household formation. That variable is considered to be exogenous.

11.eisure is assumed to be a non-inferior good. Thus, the farther an indifference curve is away from the origin, the the current period permanent marginal personal income tax rate or the permanent effective Social Security tax rate of the household, other factors constant, the lower is each individual's reservation wage rate. $^{12}$

The influence of the permanent number of members (of all ages) of the household in the current period on an individual's reservation wage rate is ambiguous. The greater the permanent number of members, other factors constant, the smaller is each individual's pro rata share of the household's permanent real income, hence, the lower is the reservation wage rate. On the other hand, the larger the permanent size of the household the greater is the amount of household time presumed to be allocated to household activities. ${ }^{13}$ As a result, each individual has less available time, and the greater are the reservation wage rates. ${ }^{14}$ The net influence of the permanent size of the household on each individual's reservation wage rate is thus ambiguous, depending on which of the two influences dominates.

It is also postulated that each individual's reservation wage rate in the current period is related to transitory factors. Each individual's reservation wage rate is positively related to the transitory components of both sources of the household's real income and

greater is the marginal rate of substitution at its intersection with the time constraint, that is, the higher is the reservation wage rate. The greater the household's permanent real income and/or the individual's share, the farther is an individual's relevant indifference curve from the origin.

12 The greater the permanent tax rates the smaller is the after tax permanent real income of the household and the individual's relevant indifference curve is closer to the origin. The effective Social Security tax rate is the ratio of the household's total Social Security tax payments to total wage income. The effective rate is used rather than the legislated rate so as to capture the influence of changes in the maximum wage income on which the tax is levied and in the number of workers covered.

43ome factors other than household size influencing the amount of household time allocated to household tasks are: the amount of time required to produce directly for the household goods and services by members of a household, the market price of goods and services similar to those produced directly by the household, and the price of education. These factors are assumed constant in this study. See Gary Becker, "A Theory of the Allocation of Time." For an enpirical study of the factors influeneing the allocation of time to househole production of goods and services for its own consumption, see Wendy Lee Gramm, "The Demand for the Wife's Non-Market Time," Southern Economic Journal (July $1974)$, pp. 124-33.

14The greater the amount of time allocated to household tasks, the closer is an individual's available time constraint to the origin. Since an individual's indifference curves are presumed to slope upward to the left in an increasing manner, their slopes are steeper as the time constraint approaches the origin. 
negatively related to the transitory components of the household's marginal income tax rate and effective Social Security tax rate. The influence of the transitory components of the household's size is ambiguous.

The preceding analysis of the factors influencing the current period reservation wage rate of an individual member of a given household is summarized in equation (1). The sign above each variable indicates its postulated direction of influence.

(1) $\mathrm{RW}_{\mathrm{i} j}=\mathrm{f}_{\mathrm{ij}}\left[\mathrm{NLI}_{\mathrm{j}}^{*}, \mathrm{WE}_{\mathrm{j}}^{*}, \operatorname{ITR}_{\mathrm{j}}^{*}, \operatorname{sSTR}_{\mathrm{j}}^{*}, \mathrm{P}_{\mathrm{j}}^{*}, \mathrm{NLI}_{\mathrm{j}}^{(+)}-\mathrm{NLI}_{\mathrm{j}}^{*}\right.$,

$$
\left.\mathrm{WE}_{\mathrm{i}}^{(+)}-\mathrm{WE}_{\mathrm{i}}^{*}, \operatorname{ITR}_{\mathrm{j}}^{(-)}-\operatorname{ITR}_{\mathrm{j}}^{\circ}, \operatorname{SSTR}_{\mathrm{j}}^{(-)}-\operatorname{SSTR}_{\mathrm{i}}^{\circ}, \mathrm{P}_{\mathrm{j}}^{(?)}-\mathrm{P}_{\mathrm{j}}^{\circ}\right] .
$$

$R W_{i j}=$ reservation wage rate of the $i^{\text {th }}$ member of $j^{\text {th }}$ household.

$\mathrm{NLI}_{i}^{\circ}=$ perceived permanent nonlabor real income of the $f^{\text {th }}$ household.

NLI $_{j}=$ actual nonlabor real income of the $\mathrm{j}^{\text {th }}$ household.

$\mathrm{WE}_{\mathrm{j}}^{\mathrm{O}}=$ percetved average permanent real wage ${ }_{15}^{\text {rate of }}$ employed members of the i $^{\text {th }}$ household.

$\mathrm{WE}_{\mathrm{j}}=$ actual average real wage rate of employed menbers of the jth lousehold.

ITR $_{i}^{*}=$ perceived permanent marginal income tax rate of the $\mathrm{j}^{\text {th }}$ household

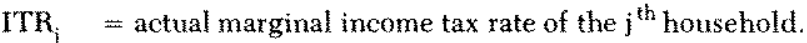

SSTR $_{j}^{\circ}=$ perceived permanent effective Social Security tax rate of the $j^{\text {th }}$ household.

SSTR $_{1}=$ actual effective Social Security tax rate of the $\mathrm{j}^{\text {th }}$ household.

$P_{i}^{*} \quad=$ perceived permanent size of the $j^{\text {th }}$ household.

$p_{j} \quad$ = actual size of the $\mathrm{j}^{\text {th }}$ household.

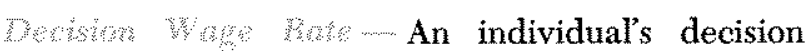

wage rate in the current period is postulated to depend on the individual's perception of the permanent real wage rate available in the market, the permanent marginal income tax rate of the household, and the individual's permanent effective Social Security tax rate. ${ }^{16}$ The greater the perceived permanent real wage rate, or the smaller the permanent tax rates, the higher is the individual's decision wage rate.

Just as in the case of the reservation wage rate, the individual's current period decision wage rate is postulated to be also related to the transitory component of each factor. It is postulated that the individual's

\footnotetext{
15 Total real income received from employed members of the household depends on the average real wage rate, the number employed, and the average number of hours worked per employed member. Attention is Tocused, however, on only the average real wage rate received so as not to complicate the analysis unduly.

1sThe individal's real wage rate reflects the intuence of such factors specinc to the individual as ase, sex, edrcation, tratning, and innate ability.
}

decision wage rate in the current period is positively related to the transitory component of the individual's perception of the market real wage rate, ${ }^{17}$ and negatively related to the transitory components of the household's marginal income tax rate and the individual's effective Social Security tax rate.

The factors influencing the individual's decision wage rate are summarized in equation (2). The sign above each variable indicates the postulated direction of influence.

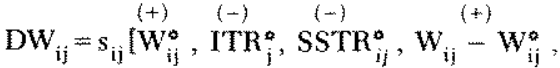

$$
\begin{aligned}
& \left.{ }^{(-)} \operatorname{TTR}_{\mathrm{j}}^{\mathrm{a}}, \operatorname{SSTR}_{\mathrm{ij}} \stackrel{(-)}{-} \mathrm{SSTR}_{\mathrm{ij}}^{\circ}\right] \\
& \text { DW }_{i j}=\text { decision wage rate of the } i^{\text {th }} \text { member in the } \\
& i^{\text {th }} \text { household. } \\
& W_{i j}^{\circ} \quad=\text { perceived permanent real wage rate of the } i^{\text {th }} \\
& \text { member in the } \mathrm{j}^{\text {th }} \text { household. } \\
& W_{i \mathrm{i}} \quad \text { = actual real wage rate of the } i^{\text {th }} \text { member in the } \\
& j^{\text {th }} \text { household. } \\
& \text { SSTR }_{i \mathrm{i}}^{\circ}=\text { perceived permanent effective Social Security tax } \\
& \text { rate of the } i^{\text {th }} \text { member of the } j^{\text {th }} \text { household. } \\
& \text { SSTR }_{i j}=\text { actual effective Social Security tax rate of the }
\end{aligned}
$$

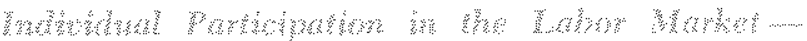

The term, $L F_{i j}$, denotes the labor force participation status of the $\mathrm{i}^{\text {th }}$ individual in the $\mathrm{j}^{\text {th }}$ household. If the individual is in the labor force, $L F_{i j}$ equals one, and if not in the labor force, $L F_{i j}$ equals zero. The individual's labor force participation status is given by the following:

(3a) $\mathrm{LF}_{i \mathrm{j}}=1$, if $\mathrm{RW}_{\mathrm{ij}}<\mathrm{DW}$ ij

(3b) $\mathrm{LF}_{\mathrm{ij}}=0$, if $\mathrm{RW}_{\mathrm{ij}} \geqslant \mathrm{DW}$

A change in the participation status of an individual in response to a given change in one of the arguments in either equation (1) or (2) depends on three conditions. They are: the existing magnitude of the difference between that person's reservation wage rate and decision wage rate, the magnitude of the response of either wage rate, and the magnitude of the change in the argument under consideration. For example, assume an increase in the perceived permanent real wage rate which increases an individual's decision wage rate. If the individual is already in the labor force there is no change in participation as $\mathrm{DW}_{\mathrm{ij}}$

\footnotetext{
17For an individual in the labor market, either employed or secking employment, some infornation regarding the wage rate is avallable. This does not hold, however, for an individuat not in the market. In this case, it is assuned that the individual obtains some information about the real wage rate from krowledge of the rates recened by the employed
} members of the household or by other individuals. 
exceeds $\mathrm{RW}_{1,}$ by an even greater amount than previously. On the other hand, if previously $D W_{i j}=$ $R W_{i j}$, the individual now enters. But, if $\mathbb{R} W_{1 j}$ exceeded $\mathrm{DW}_{i j}$ by a large amount, for the individual to enter the labor force either the response of $\mathrm{RW}_{i j}$ to a small change in $W_{j j}^{*}$ must be large or the change in $W_{i j}^{*}$ must be large if the response is very small.

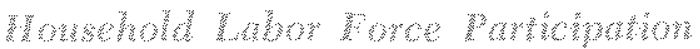

The total number of members of labor force age in a household participating in the labor market $\left(\mathrm{LF}_{\Downarrow}\right)$ in the current period is the sum of the total number of individuals whose reservation wage rates are less than their decision wage rates. Given the postulated individual behavior, the total number of individuals in a household participating in the labor market depends on the number of individuals of labor force age $\left(\mathrm{PL}_{j}\right)$ and the reservation wage rate of each, relative to the decision wage rate.

In moving the unit of analysis from one individwal within a household to the household, it becomes impossible to derive, unambignously, the response of the household's aggregate labor force participation without specific knowledge regarding the interactions of the individual members. This is because the decisions of each nember with regard to participation exert an influence on the decisions of all other members (see shaded insert). This follows from equation (1) in which the reservation wage of every member depends on the perceived average permanent real wage rate received by employed nembers and their actual average real wage rate.

Without sufficient information regarding the interdependent behavior of each member of a household, the response of the aggregate participation of household members is ambiguous. Moreover, the response can change over time given different initial conditions in terms of the magnitude and sign of the discrepancy between each member's reservation wage rate and decision wage rate. Also, the response can change over time as the magnitude of change in each independent variable changes.

The relationship for the number of individuals of a household in the labor market is given by equation (4). It is assumed that all of the permanent variables and the related actuat variables in equations (1) and (2) move in the same manner as their average values in the market. Thus, subseripts on these variables are dropped and the variables are defined as in the above assumption. All of the signs are now ambiguous, as discussed earlier, except for the positive sign associated with the household's population of Iabor force age.

$$
\begin{aligned}
& \text { (4) } L F_{j}=h_{1}\left[N L H^{*}, W^{*}, I T R *, S S T R *, P^{*}, N L I-N I^{*}\right. \text {, } \\
& \text { W-W } \text { W }^{*} \text { TTR-ITR*, SSTR-SSTR*, } \\
& \left.P-P^{*}, P L_{j}\right]
\end{aligned}
$$

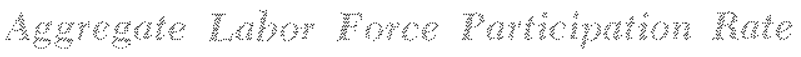

The simplifying assumption that all households are identical is made in aggregating labor force participation across households. ${ }^{18}$ As a consequence, the total number of individuals in the labor force (LF) in the current period is given by multiplying equation (4) by the number of households $(\mathrm{H})$. Assuming that equation (4) is homogeneous of degree one in PL, $\mathrm{P}^{\phi}$, and $\mathrm{P}$, and dividing both sides by $\mathrm{H}$, yields the equation for the aggregate labor force participation rate (LF/PL).

(5)

$$
\begin{aligned}
& \frac{\mathrm{LF}}{\mathrm{H} * \mathrm{PL}_{\mathrm{i}}}=\frac{\mathrm{LF}}{\mathrm{PL}}=h_{\mathrm{j}}\left[\mathrm{NLI}^{\circ}, \mathrm{W}^{*}, \operatorname{ITR}^{\circ}, \mathrm{SSTR}^{*}, \mathrm{P}^{*} / \mathrm{PL}\right. \\
& \text { NLI-NLI" } W-W^{*}, \text { ITR }-I T R * \text {, } \\
& \text { SSTR-SSTR*, P/PL-P*/RL\}. }
\end{aligned}
$$

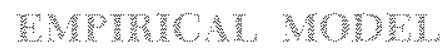

The theoretical model has been expressed in general mathematical terms in equation (5). It now becomes necessary to state that equation in a specific form in order to estinate its parameters. It is assumed that the relationship is linear in natural logarithms. There remains an additional problem to be cleared up in developing the empirical form of the model which is estimated. That problem is with regard to the formation of perceptions of the permanent components.

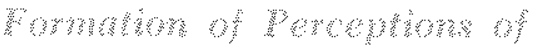

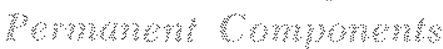

The perceived permanent component of each variable in equation (5) cannot be observed. It is assumed that perceptions regarding the permanent level of each variable change in the current period in response to the discrepancy between the actual and perceived permanent levels of the variable in the previous period. An example of this adiustment process is presented in equation (6).

(6) $\left.\ln W_{!}^{0}-\ln _{i-1}^{*}=\ln _{1-1}-\ln W_{i-1}^{*}\right]_{1}$

\footnotetext{
3athis assumption imples that the are mo distributional in Inences on overnll labor fore participation, such as changes in the distribution of nonlabor incme amone households, on chat such intuences are small onough to be ignored.
} 


\section{Sources of Uncertainty}

The uncertainty regarding the response of aggregate labor force participation in the household can be illustrated by two cases. The examples are not exhaustive, but they do sef forth the general considerations involved in postulating the response of aggregate labor force participation at the household level. For purpose of illustration, only the infuence of a change in the average market real wage is analyzed. The analysis can readily be extended to other variables.

Casp I - Suppose that there are two nembers (a man and a woman) of labor force age in a particular household and that at prevaiting individual perceptions of pemanent and transitory real wage rates, nonlabor real income, and tax rates, both are in the labor force and are employed. Assmme further that both the per ceived pemanent manket real wage rate and the actual real wage rate of each individual have a fixed relationship to the average market real wage rate paid in the economy. These proportions vary between individuals, say tor example, because of difterent levels of educaHon. Also assume that the woman's decision wage rate is only slighty greater than her reservation wage rate and that the man's decision wage rate is very large relative to his reservation wage rate. The woman is then the narginal worker in this household.

Given these assumptions, conditons can be set forth under which the response of the aggregate household labor force participation to a given increase in the average makket real wage is either negative or zem. If the response of the woman's reservation wage rate wih regatd to an norease in the man's actual real wage rate is greater than the response of her own decision wage rate, then she, being the marginal workex, drops out of the labor force. The man's resorvation wage rate falls as a result, because the woman no longer brings income to the household. But since his decision wage rate increases, the diference between his reservation and decision wage rate widens and he remans the theor force, on the other hand, if the responses of each tucividuals reservation wage rate and decision wage rate are equal, both stay in the labor force.

Gase 7 - This case illustrates condtions under which the response of aggregate household participa-

The adjustment coefficient is $\lambda$, which can take on values from zero to minty. If $\lambda=0$, there is no adjustment; if $\lambda=1$, there is full adjustment in the current period. For $0<\lambda<1$, there is partial adjustment in the current period.

Next, it is assumed that the adjustment coefficients are equal in the formation of perceptions regarding all permanent variables in order to simplify the algebra from that which is involved when the adjustments proceed at different rates. An equation similar to $(6)$ tion is either positive or zero. Assume that the man is in the labor force and is employed and that his decision wage rate greatly exceeds his reservation wage rate. Also, assume that the woman is not in the labor force but is at the margin because, for her, the two wage rates are equal. She, as the marginal individual in the household, will enter the labor force if the response of her decision wage rate to an increase in the market real wage rate is greater than the response of her reservation wage rate. If she finds employment, the man will remain in the labor market if the response of his decision wage rate is greater than the response of his reservation wage rate to the additional household income brought in by the newly employed member. On the other hand, if the response of each individual's reservation wage and decision wage rate are equal, their labor market participation remains unchanged.

Implications - The two cases indicate that changes in the aggregate participation of household members are influenced by the response of each member's reser. vation wage rate to a change in the average market real wage rate, relative to the response of the decision wage rate of each of them. The magnitude of the discrepancy between each members reservation wage rate and decision wage rate, along with the magnitude of the change in the average market real wage rate, also exerts an important influence on aggregate participation. This last point can be illustrated by another example.

If, in Case II, the individual who was at the margin had instead a reservation wage rate in considerable excess of her decision wage rate, she would enter the labor force only if there were a sufficiently large increase in the average market real wage rate. Suppose, however, that she did enter and was employed. What happens to the employed individual? If he were at the margin of the labor force (instead of having a large decision wage rate relative to his reservation wage rate), he would leave the labor force due to the added income to the household contributed by the newly employed member. The net result would not be a change in aggregate participation, only a change in the individuals who are involved.

for each of these variables is substituted into equation (5) and the lagged perceived permanent levels of the variables are eliminated by a koyck-type transfomation. The resulting equation is solved for $\ln [\mathrm{LF} / \mathrm{PL}]$, which yields the following: ${ }^{2}$

\footnotetext{
$195 e$ L. M. Koyck, Distributed Lags and Investment Atulyst (Ansterdam: North-Holland Publishing Co., 1954), pp. $22-24$.

207he equation could also have been witten in terms of curtent period and lagged period levels, for example,

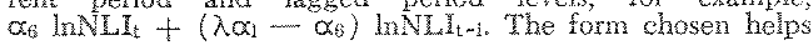


(7)

$$
\begin{aligned}
& \ln [L F / P L]_{t}=\lambda \alpha_{0}+\lambda \alpha_{1} \operatorname{lnNLI} I_{t-1} \\
& +\lambda \alpha_{2} \ln \mathrm{W}_{\mathrm{r}-1}+\lambda \alpha_{3} \operatorname{lnITR} \mathrm{t}_{-1} \\
& +\lambda \alpha_{4} \operatorname{lnSSTR} \mathrm{t}_{\mathrm{t}-1}
\end{aligned}
$$

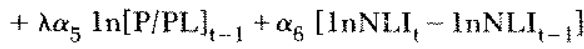

$$
\begin{aligned}
& +\alpha_{7}\left[\ln \mathrm{W}_{\mathrm{t}}-\ln \mathrm{W}_{\mathrm{t}-1}\right]
\end{aligned}
$$

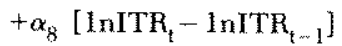

$$
\begin{aligned}
& +\alpha_{9}\left[\operatorname{lnSSTR} t-\operatorname{lnSSTR} \mathrm{ST}_{t-1}\right] \\
& +\alpha_{10}\left[\ln (\text { P/PL })_{t}-\ln (\mathrm{P} / \mathrm{PL})_{\mathrm{t}-1}\right] \\
& +(1-\lambda) \ln [\mathrm{LF} / \mathrm{PL}]_{\mathrm{t}-1} \text {. }
\end{aligned}
$$

$$
\begin{aligned}
& \text { LF = number of individuals in the labor force. } \\
& \text { PL = number of individuals of labor force age. } \\
& \text { NLI = nonlabor real income per hotsehold. } \\
& \text { W = average real wage rate. } \\
& \text { ITR = average effective personal income tax rate. } \\
& \text { SSTR = average effective personal social Security tax rate. } \\
& \text { P }=\text { total population. }
\end{aligned}
$$

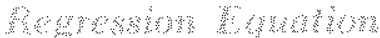

Next, equation (7) is expressed as a regression equation which provides the basis for estimating the parameters of the specific empirical equation used for the analysis in Part II of this article. In the regression form of equation (7), the regression coefficients reflect the following structural coeflicients:

$\begin{array}{ll}a_{0}=\lambda \alpha_{0} & a_{6}=\alpha_{6} \\ a_{1}=\lambda \alpha_{1} & a_{7}=\alpha_{7} \\ a_{2}=\lambda \alpha_{2} & a_{8}=\alpha_{8} \\ a_{3}=\lambda \alpha_{3} & a_{9}=\alpha_{9} \\ a_{4}=\lambda \alpha_{4} & a_{10}=\alpha_{10} \\ a_{5}=\lambda \alpha_{5} & a_{11}=1-\lambda .\end{array}$

The influence of the permanent and transitory components of each factor can be readily identified from the structural coefficients embodied in each regression coefficient. The lagged terms, except $\ln [\mathrm{LF} / \mathrm{PL}]_{\mathrm{E}-\mathrm{l}}$, represent the influence of the permanent components, and the first difference terms represent the infuence of the transitory components. The lagged participation rate term incorporates the lag in the formation of perceptions regarding the current period permament level of each variable.

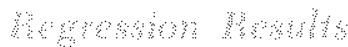

The coefficients of the model are estimated by ordinary least squares regressions. Quarterly time

redice the estimation problem (multicolinearity) that arises from having both contemporaneous and lagged levels of each variable. It also provides a straightforward estimation of the permanent and transitory infuences. series data for the period I/1957 to IV/1976 are used (see Appendix for data sources). All data are seasonally adjusted.

Civilian noninstitutional labor force and total population data are taken from Department of Labor sources. ${ }^{21}$ Anmual estimates of the number of households by the Bureau of the Census are interpolated to provide quarterly estimates. The average real wage rate is the average hourly compensation of employees in the private economy (adjusted for employer Social Security contributions) deflated by the consumer price index. Nonlabor real income per household is the sum of personal interest, dividends, proprietor's income, net rent and Social Security payments deflated by the consumer price index and then divided by the number of households. The average effective personal income tax rate is total personal income tax payments divided by the difference between personal income and government transfer payments to individuals. The average effective personal Social Security tax rate is worker contributions to Social Security divided by the sum of wages and salaries.

The estimated parameters of the regression equation are reported in the first column of Table $I$. The equation was tested for a structural change after IV/ 1964, when the trend in the labor force participation rate changed from a small negative to a rather large positive trend (see Chart I). The original equation was reestimated with the additions of a dummy variable, $\mathrm{D}=1.0$, for the period after IV/1964 (to allow for a change in the constant) and $D$ times each variable (to allow for a change in each variable's regression coefficient). The results of the reestimation are reported in the second column of Table $I$. The $F$ test $(\mathrm{F}=2.06$ ) rejects at the 5 percent level of signifcance the null hypothesis that all the estimated coefficients of $D$ and the variables multiplied by $D$ are zero. The test thus rejects the hypothesis of no change in structure.

\footnotetext{
21These data are adiusted by the author to eliminate aiscontinuities resulting from the addition of data for Alaska and Hawaif when they were granted statehood and benchmark adjustments made following the 1960 and 1970 Censuses. The adjustments made are based on overlap data reported at the time of each adjustment.

22The reasons for such a change in response after 1964 cannot be ascertained from the model. The specific empinical form of the model used in this study is reported in Table I, Columin III. The changes in the estimated responses of the labor force participation rate with respect to the average permenent real wage rate and the transitory component of the average effective personal Social Security tax rate, however, suggest the channel through which the change occurred bet not the basic source. Both of these changes imply that, on average, the aggregate labor force partici-
} 
Tablo 1

EST MATED COFFFICIENTS

\begin{tabular}{|c|c|c|c|c|c|c|}
\hline & Coefficlent & $(t)$ & Coefficient & $(t)$ & Coefferent & $(1)$ \\
\hline$\Delta 1 \mathrm{nNL}$ & $\checkmark, 026$ & 1.004 &, .060 & 560 & 0,043 & 1,960 \\
\hline$\Delta 1 \mathrm{nW}$ & +140 & 2525 & -072 & 609 & +137 & 2719 \\
\hline$\triangle \mathrm{mHT}$, & -002 & 878 & -064 & 2183 & $\$ 050$ & 2660 \\
\hline$\triangle 1 \mathrm{ssTR}$ &, 008 & 972 & 006 & 337 & $\$$ & 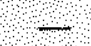 \\
\hline$\Delta \mathrm{Tr}(\mathrm{P} / \mathrm{PL})$ & 513 & 2.215 & 460 & 905 & 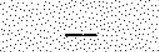 & $\underline{s}$ \\
\hline $1 \mathrm{NNI}_{1}$ & 2009 & 644 & 4008 & 321 & $\$ 010$ & 2370 \\
\hline $1 n W-1$ & 2004 & 232 & & 872 & 1072 & 3653 \\
\hline $1 n i r n_{t}$ & 010 & 1.700 & 1029 & 1,483 & $\stackrel{?}{?}$ & 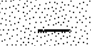 \\
\hline $158 S 1 M_{1}$ & 004 & 864 & 048 & 2,156 & 022 & 4090 \\
\hline $11,(\mathrm{P} / \mathrm{P}) \mathrm{H}, \mathrm{U}$ & 4116 & 3.851 & 144 & 663 & 4098 & 2845 \\
\hline $17(1 \mathrm{~T} / \mathrm{Pl}) \mathrm{t}$ & 1649 & 8560 & 430 & 20013 & 481 & 6387 \\
\hline Constant & 147 & 1.654 & 260 & 818 & 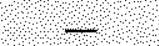 & 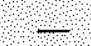 \\
\hline $\mathrm{D} \cdot \mathrm{AlN}_{\mathrm{N}} \mathrm{H}$ & & & 1023 & 211 & + & 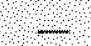 \\
\hline $\mathrm{O} \cdot \mathrm{\Delta l} \ln \mathrm{W}$ & & & 4079 & 582 & 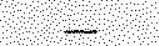 & $\$$ \\
\hline $\mathrm{D} \cdot \mathrm{AlnIIA}$ & & & 026 & 2603 & 044 & 2,250 \\
\hline D. $\triangle$ InSSTR & & & $\$ 009$ & 458 & 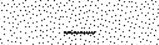 & 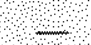 \\
\hline $\mathrm{D} \bullet \Delta / \mathrm{N}(\mathrm{P} / \mathrm{PL})$ & & & 4510 & 857 & 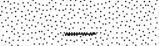 & $\underline{ }$ \\
\hline $\mathrm{D} \cdot 1 \mathrm{nNL}, \rightarrow$ & & & 035 & 296 & \& & 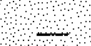 \\
\hline $\mathrm{D} \cdot \mathrm{lnW}$, & & & 108 & 955 & 099 & 3040 \\
\hline $\mathrm{D} \bullet \mathrm{GINA}_{1}$ & & & 039 & 1876 & 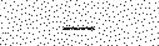 & ? \\
\hline D $\cdot$ lnssTht $_{-}$ & & & 1085 & 144 & 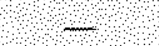 & 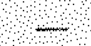 \\
\hline $\mathrm{D} \bullet \mathrm{ln}(\mathrm{P} / \mathrm{P}),-1$ & & &,+ 024 & 107 & 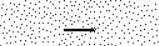 & $\square$ \\
\hline $\mathrm{D} \bullet 1 \mathrm{n}(\mathrm{LF} / \mathrm{PL}) / \mathrm{l}$ & & & 031 & 129 & 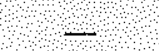 & 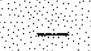 \\
\hline D & & & -402 & 483 & -110 & 3804 \\
\hline $\mathrm{R}^{2}$ & 078 & & 984 & & 981 & \\
\hline $\mathrm{SE}$ & 00255 & & 00234 & & 00232 & \\
\hline DW & 2200 & & 2,204 & & 2,000 & \\
\hline
\end{tabular}

A similar test for a change in structure was also performed for the period after 1973. That period was the one in which the labor force participation rate moved in a different manner from that predicted by the discouraged worker hypothesis. The regression form of equation (7) was estimated for the sample period I/1965 to IV/1976, the period found in the previous test to have a structure different from that of the I/1957 to IV/1964 period. Then the dummy variable $D=1.0$ after $I V / 1973$ was introduced, and the equation was reestimated as in the previous test. The $F$ test $(F=1,10$ ) does not reject at the 5 percent level of significance the null hypothesis that the esti-

pation of individuals became more responsive after 1964 to the aftertax real wage rate of indwiduals relative to the aftertax real incone that households receive from employed members. Other studies of the participation rate have visiably relied on a dmmy variable to capture the change in the trend, without identifying specific channels through which the change occurred. See studies listed in footnote 3 . mated coefficients of all the added variables are zero. Thus, the test does not reject the hypothesis of no change in structure after IV/1973.

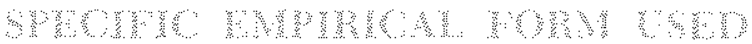 THPMB}

Additional tests resulted in the estimated equation reported in the third colum of Table $I$. The $F$ test $(F=.93)$ did not reject at the 5 percent level of significance the null hypothesis that all the omitted coefficients from the second column are zero. The estimated equation reported in Table 1 , Colum 3 , is used in the balance of this study.

The estimated equation projects the level of the labor force participation rate with small errors within the sample period. The equation explains 98 percent of the variance in the level of the labor force partici- 

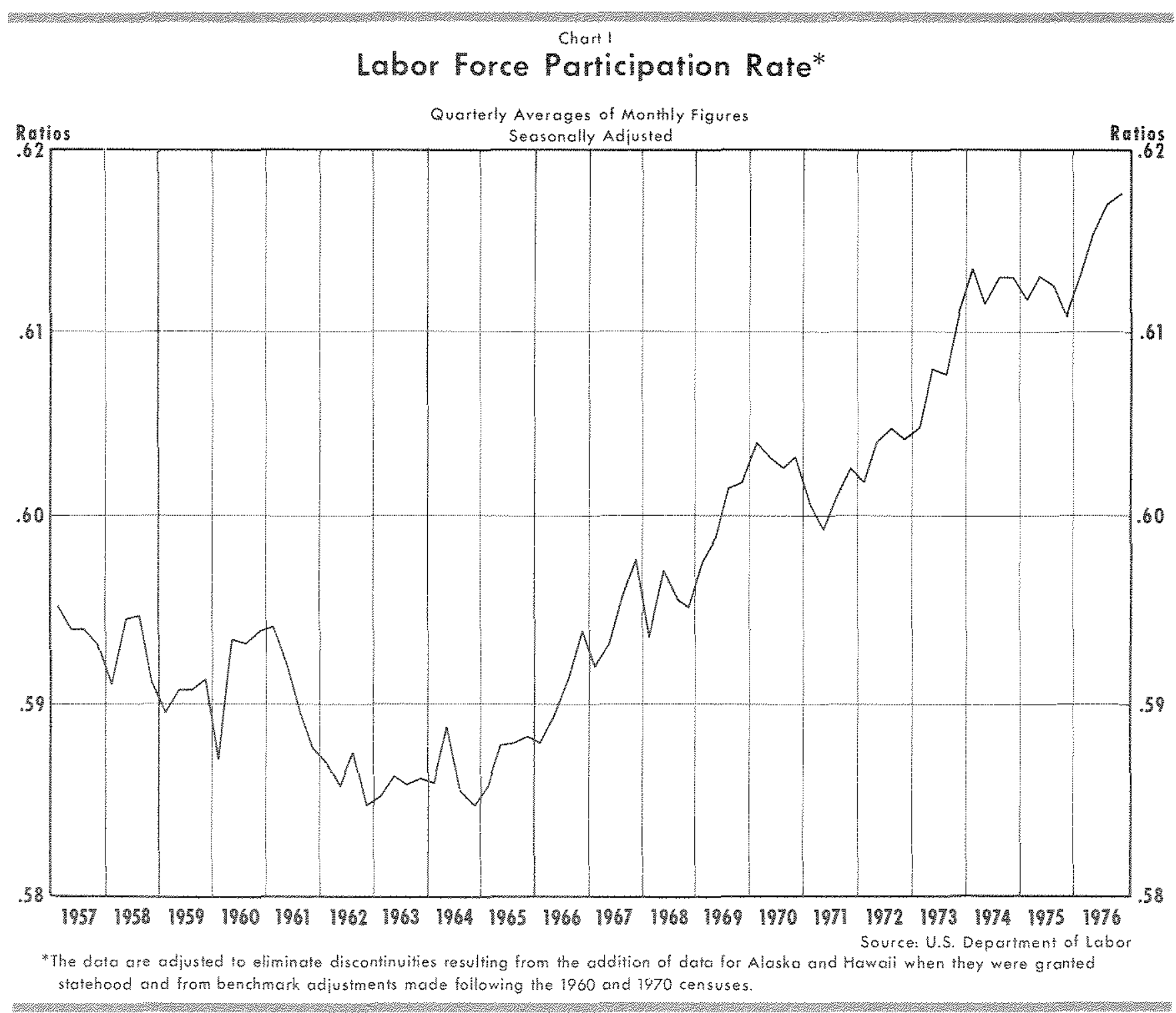

pation rate. The standard error is, 0023 , or about onefouth of one percent.

Such projections, however, are based on known values of the lagged participation rate. The question thus arises regarding the ability of the model to gen erate profections several cuarters ahed when simulated levels of the lagged participation rate are used instead of known levels. The model was simulated dynmically over the sample period using the actual level of the lagged participation rate for the first cuarter of 1957 and then using the simulated level thereafter.

The simulation results are presented in Chart 11 . A comparison of the actual and simulated levels indcates that the nodel smulates the labor force partici. pation rate very well. The simulation picks up the change in trend after 1964 and there are no prolonged periods of over or under projections. The correlation between the actual and simulated levels is .99 . The largest absolute error is 59 percent in $1 / 1958$. The root-mean-squared error is 24 percent, only slightly larger than the standard error of the estimated equation. The error for the last quarter of the simulation is 50 percent, indicating that the errors do not accumulate significantly over time. There is virually no systematic bias in the simuintion as indicated by an average error of -.01 percent. ${ }^{23}$

23 Arother measure of simulation accuracy is Thel's inequalty coeftient, "The wefhoient for the dymmic simulation resuts is 002 compared with a coeflicient of ztro for perect fore. casts. Decomposition of the total aror indicates that the 


\section{Results of Ex Post Dynamic Simulation Labor Force Participation Rale}

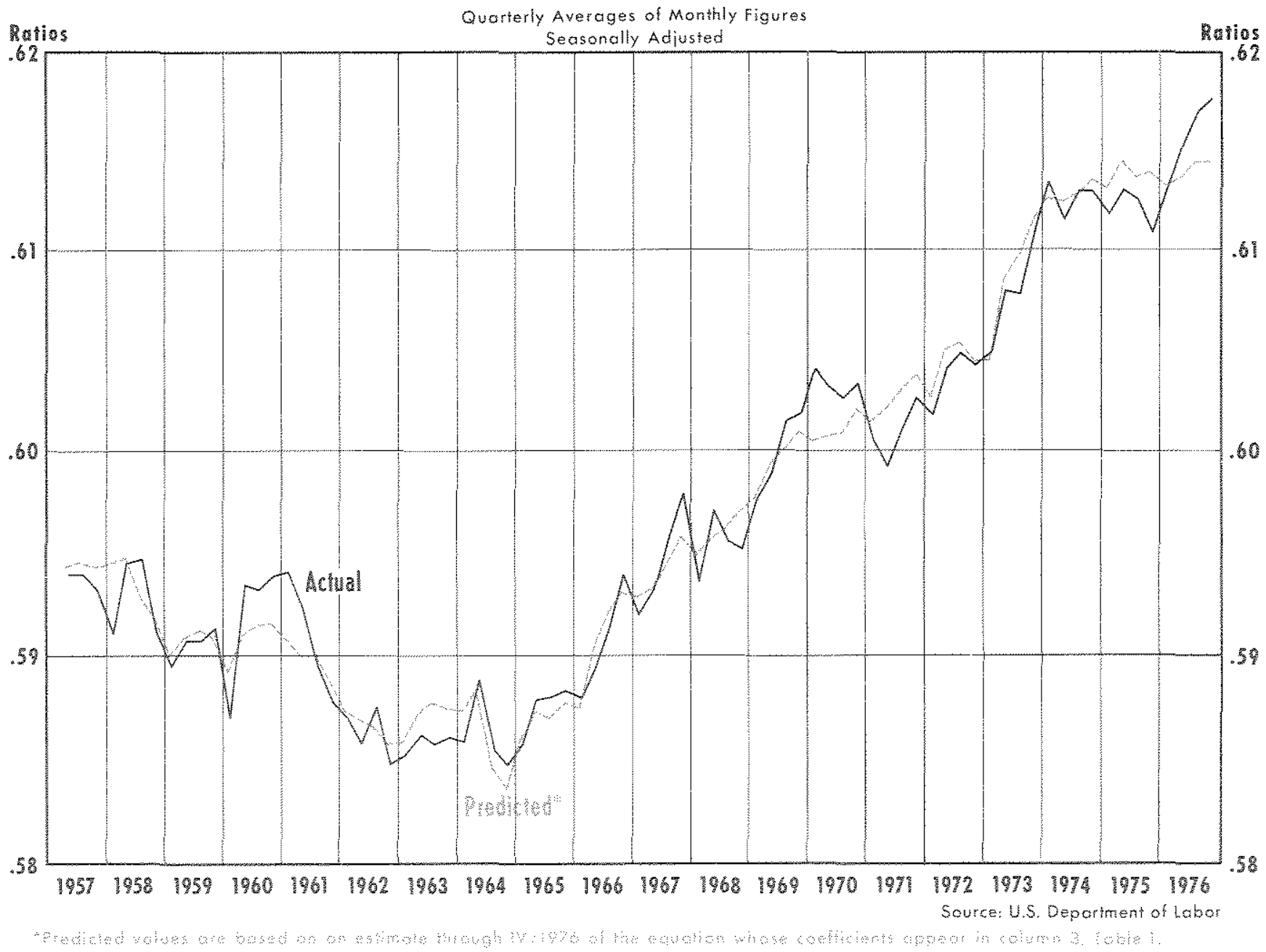

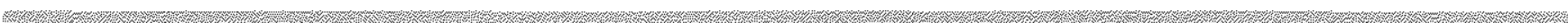

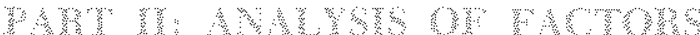

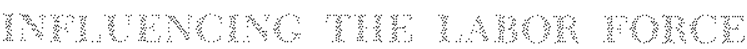

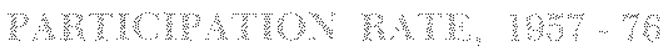

The empirical model developed in part 1 can be used to analyze the factors infuencing the overall labor force participation rate during the period from 1957 to 1976 . Three subperiods are used. They are 1957 to 1964,1965 to 1973 , and 1974 to 1976.

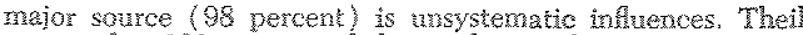
argies that 100 percent of the total error from minstematio

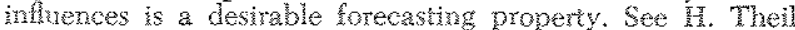
Economio Forectso and polict (Amsterdan: North-Holland Prblishing $\mathrm{Co}, 1958)$, pp. 31-38, for a discussion of the inemually coentcient, its decompostion, and intorpretations
There are two stages in the analysis for each subperiod. First, the relative contribution of each item reported in Table I, Column 3 , is ascertained for each subperiod by converting the estimated response of the participation rate to a standardized statistical measure called the beta coefficient. ${ }^{2}$ The larger a variable's beta coeflctent, without regard to sign, the greater is the contribution. The beta coeffeients in each of the subperiods are reported in Table II. Next,

\footnotetext{
24 The bets coeficien for an explanatary variable is its estimated regrosion colficient runliviled by the ratio of the stander devation of that varable to the standard fextation of the dependent wrable. Sepante calculations of the shandard devatons are made for each sebperiod.
} 


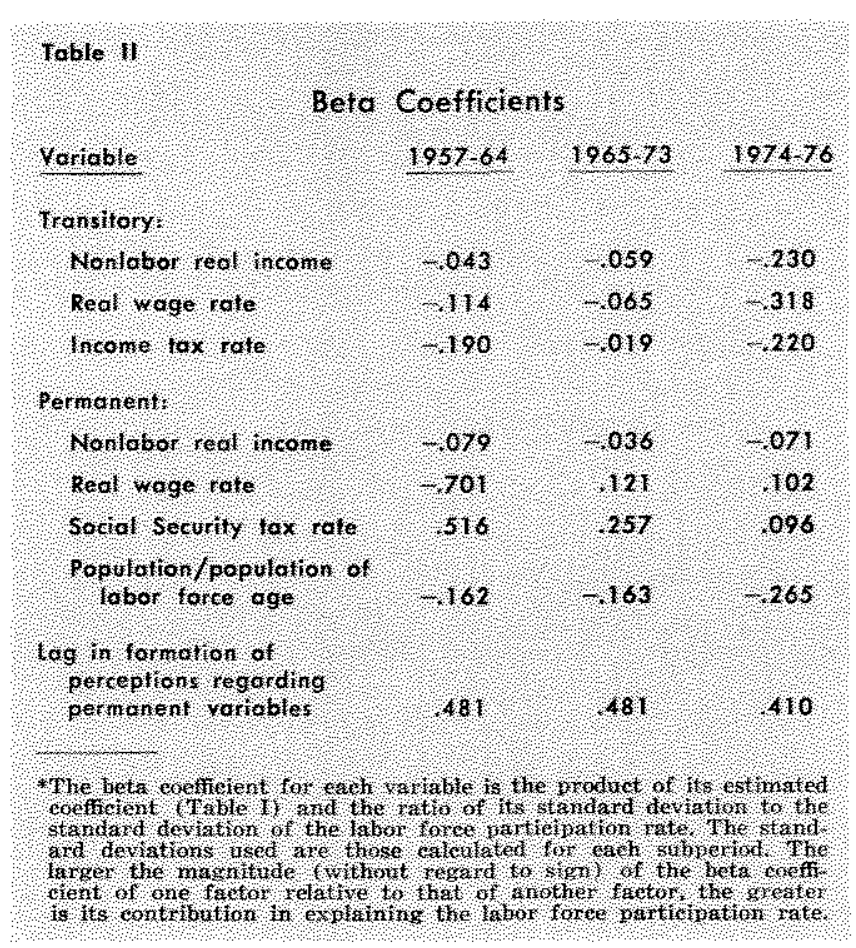

the directions of influence of the dominant forces, as indicated by the beta coefficients, are ascertained from observed movements in the underlying data within the subperiod and the sign of each coefficient.

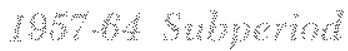

An examination of the relative magnitudes of the beta coefficients (without regard to signs) for the 1957-64 subperiod (Table II) indicates that trend influences were the most important in explaining movements in the labor force participation rate. The largest influence was the permanent component of the average real wage rate; the second largest, the permanent component of the average effective personal Social Security tax rate; and the fifth largest, the permanent component of the ratio of total population to population of labor force age. The major short-run influence was the lag in the formation of perceptions regarding the permanent level of each variable. Its beta coefficient was the third largest.

The direction of influence of each permanent component on the trend in participation is identified by examining the longer-run movements in the underlying variables that existed within at least a major portion of the 1957-64 subperiod. Nonlabor real income per household rose at a 3.8 percent average anmual rate from $\mathrm{W} / 1960$ to $\mathrm{IV} / 1965$; the average real wage rate rose at a 2.5 percent rate from IV/ 195 m to IV/1968; and the average effective personal Social Security tax rate rose at a 5.5 percent rate from U/1957 to $I / 1966$. The ratio of total population to population of labor force age rose at a 0.6 percent rate from IV/1957 to IV/1961, followed by little change to IV/1966. Given the estimated signs of the coefficients of the permanent components, all the variables mentioned, except the average effective personal Social Security tax rate, moved in such a manner as to produce the negative trend in the labor force participation rate during the 1957-64 subperiod.

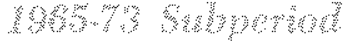

Table II indicates that, during the 1965-73 subperiod, trend influences on the labor force participation rate were still of major importance. In terms of beta coefficients, the permanent component of the average effective personal Social Security tax rate ranked second; the permanent component of the ratio of total population to population of labor force age ranked third; and the permanent component of the average real wage rate ranked fourth. The dominant short-run influence was the lag in the formation of perceptions regarding the permanent levels of the variables, as in the previous subperiod.

Three of the variables continued to rise, but at slower rates than in the 1957-64 subperiod. Nonlabor real income per household increased at a 1.6 percent annual rate from IV/1965 to IV/1973; the average real wage rate rose at a 1.0 percent rate from IV/1968 to IV/1973; and the average effective personal Social Security tax rate increased at a 2.3 percent rate from $\mathrm{l} / 1966$ to IV/1972. The movement in the ratio of total population to population of labor force age changed directions from that of the previous subperiod, decreasing at a 0.8 percent rate from IV/1966 to IV/1973.

Movements in all but one of the variables mentioned contributed to the positive trend in the participation rate during the $1965-73$ subperiod. The exception was the rise in nonlabor real income per household, which had a relatively unimportant influence according to Table II. Although the average real wage rate continued to rise in the subperiod, the sign of its coefficient changed from negative to positive (see the discussion of this change in footnote 22). Thus, the rise in the average real wage rate exerted a positive infuence on the trend of the participation rate, whereas in the previous subperiod it had exerted a negative influence. 


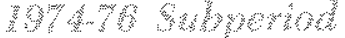

In contrast to the previous two subperiods, movements in the labor force participation rate were dominated by short-run influences during the 1974-76 subperiod. While the lag in the formation of perceptions regarding the permanent levels of the variables was the dominant short-run influence, the transitory components also exerted a significant influence. According to Table II, the transitory component of the average real wage rate ranked second; the transitory component of nonlabor real income per household ranked fourth; and the transitory component of the average effective personal income tax rate ranked fifth. The dominant long-run influence was the permanent component of the ratio of total population to population of labor force age which ranked third.

Three of the variables fluctuated widely during the 1974-76 subperiod. Nonlabor real income per household fell at a 7.3 percent annual rate from IV/ 1973 to $\mathrm{I} / 1975$ and then rose at a 2.7 percent rate through IV/1976. The average real wage rate decreased at a 2.7 percent rate from $1 / 1973$ to $I / 1974$, was about unchanged to the end of 1975 , and then rose at a 3.9 percent rate through IV/1976. There was a great drop in the average effective personal income tax rate in $11 / 1975$ followed by a substantial rebound through the period ending IV/1976. Movements in the other two variables were less volatile over the subperiod. The average effective personal Social Security tax rate rose only slightly from I/1973 to IV/1976, while the ratio of total population to population of labor force age continued to fall steadily at a 0.9 percent annual rate.

Given such a short interval of time from 1974 to 1976, it is exceedingly difficult to relate, with any degree of precision, observed movements in the aggregate labor force participation rate to specific longrun and short-run influences. Movements in the average effective personal Social Security tax rate and the ratio of total population to population of labor force age suggest that the previous subperiod's upward trend in the participation rate continued in the last subperiod. The decreases in the first part of the subperiod in nonlabor real income per household and the average real wage rate and the sharp decrease in the average effective personal income tax rate in early 1975 suggest that the participation rate was above its underlying trend at that time. Subsequent movements in the three variables would seem to indicate that by the end of 1976 the participation rate was close to its underlying trend value.

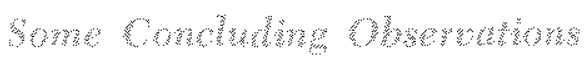

The preceding analysis identified the major "proximate" influences on movements in the labor force participation rate over 1957-76. The term "proximate" is used because each of the variables cited in the analysis responds to many independent influences. For example, both the average real wage rate and elements of nonlabor real income per household are determined by the interaction of demand and supply in many markets. Thus, observed values of these two variables reflect the joint influence of many factors, such as advancements in technology, government actions, and influences from outside the United States economy. Changes in the ratio of total population to population of labor force age reflect changes in the age distribution. Changes in the two average effective tax rates reflect changes in tax laws.

It is difficult to identify and to trace out all the independent influences on the labor force participation rate during the 1957-76 period, so only some conjectures can be offered regarding the independent influences believed to be important.

The earlier analysis suggested that movements in the participation rate in the 1957-64 subperiod were dominated by trend influences. The subperiod was characterized by great advances in technology and a boom in capital formation, both of which contributed significantly to the rising average real wage rate. Legislation increasing the tax rate and expanding the number of workers covered increased the average effective personal Social Security tax rate. The rise in the ratio of total population to population of labor force age reflected the postwar "baby boom"; that is, population under 16 years of age rose faster than population of 16 years and over.

Movements in the participation rate in the 1965-73 subperiod were also trend dominated. There were two major trend influences. One was the increase in the average effective personal Social Security tax rate due to legislation which increased the basic tax rate, raised the maximum level of wage income to which the rate applied, and expanded the coverage. The other influence was the decrease in the ratio of total population to population of labor force age as the individuals born during the "baby boom" began to turn 16 and the birth rate declined. 
In the 1974.76 subperiod, transitory influences dominated movements in the labor force participation rate. There was markedly greater short-run variability in the average real wage rate, nonlabor real income per household, and in the average effective personal income tax rate than earlier. One interpretation of the source of the increased variability in the first two factors attributes the variability to the great increase in the relative price of energy in 1974 which resulted in a reduction in the economy's ability to produce goods and services. ${ }^{2 \bar{s}}$ According to that interpretation, the reduction in productive potential decreased the average real wage rate and nonlabor real income per household in the subperiod. As a result of the

25See Robert H. Rasche and John A. Tatom, "Energy Resources and Potential GNP," this Review (June 1977), pp. $10-24$. temporary tax rebate adopted in response to the then on-going recession, the average effective personal income tax rate fell sharply in the first half of 1975 and then rebounded quickly,

A final observation is that the influence of the postwar "baby boom" on movements in the overall participation rate has been greatly overemphasized by some analysts. They argue that a major reason the aggregate participation rate decreased up to 1964 was that mothers stayed home to care for the children. And, then, as the children became older, the mothers entered the labor market and the participation rate began to rise. The analysis presented in this article, however, found that while the influence of the "baby boom" on the labor force participation rate was important, economic factors generally exerted a greater influence.

\section{APPENDIX \\ DATA SOURCES}

From: U.S. Department of Commerce

The National Income and Product Accounts of the United States, 1929-1974, A supplement to the Surcey of Current Business

Table 2. I, line 16

Old Age, Survivors', Disability, and Health Benefits. ${ }^{ \pm}$

, line 12

Rental Income of Persons with Capital Consumption Adjustment.

Dividends. ${ }^{1}$

$$
\text { , line } 13
$$

, line 14

Personal Interest Income. ${ }^{ \pm}$

, line 9

Proprietor's Income with Inventory Valıation and Capital Consumption Adjustments. ${ }^{1}$

From: U,S, Department of Commerce, Bureau of the Census

1Updated through IV/1976 using July 1976 and 1977 issues
of the Survey of Curtent Business.
Current Population Reports, Population Characteristics, Series P-20, nos. $140(7 / 2 / 65), 266(7 / 74)$, $313(9 / 77)$

Households, Total

Population per Household, Average of All Ages

From: U.S. Department of Labor, Bureau of Labor Statistics

Bureau News releases

Consumer Price Index, All Items (unrevised) ${ }^{2}$

Industry Analytical Ratios for the Private Business Sector

Real Hourly Compensation of All Employees ${ }^{3}$

Employment and Earnings

Popilation, Total, Non-institutional, Aged 16 and Over (quarterly averages of monthly data)

2Published in unadusted form and seasonaly adjusted by this Bank using Department of Labor seasonal factors. Note that this particular unadjusted series ended with June 1978 data.

"Data appear in nonindexed form to three decirnal places (updated as of January 26,1978 ). 
Civilian Labor Force, All Ages 16 and Over (quarterly averages of monthly data)

The Personal Income Tax and Social Security Tax Rates were compiled by this Bank using the Survey of Current Business data series which appear in The National Income and Product Accounts of the United States, 1929-1974 and in the July 1976 and 1977 issues of the Survey.

Personal Income (Table 2.1, line 1); Transfer Payments to Persons (Table 3.2, line 31 ); and Personal Tax and Nontax Receipts (Table 3.2, line 2).
Formula: TAX $\div$ (INCOME - TRANSFER PAYMENTS $)=$ Effective Personal Income Tax Rate.

Contributions for Social Security Insurance (Table 3.2, line 19) and Wage and Salary Disbursements (Table 2.1, line 2)

Farmula: CONTRIBUTIONS $\div$ WAGES = Effective Personal Social Security Tax Rate.

All data series are seasonally adjusted except Bureau of the Census household data.

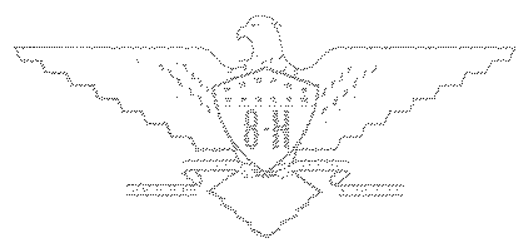

